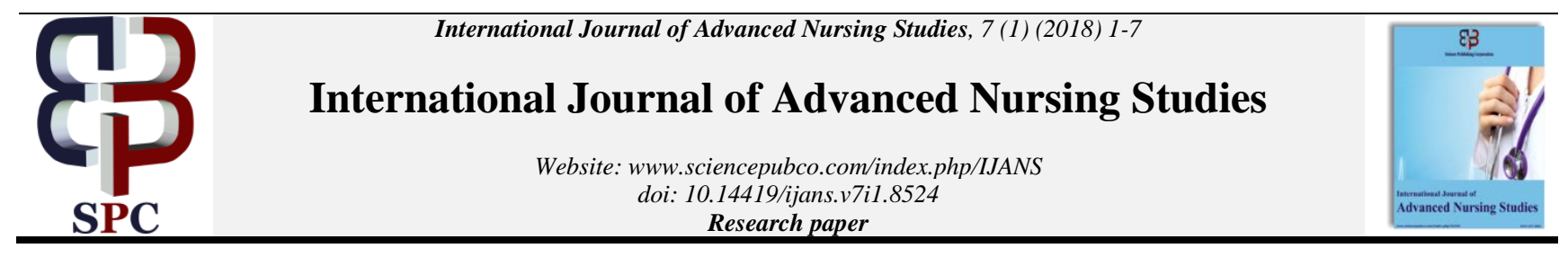

\title{
Stem cells: knowledge and attitude among health care providers in Qassim region, KSA
}

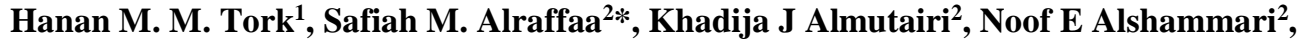 \\ Amani A Alharbi², Awatef M Alonzi \\ ${ }^{1}$ Assistant professor of child and adolescent health nursing, College of Nursing, Qassim University, KSA \\ ${ }^{2}$ Internship student, College of Nursing, Qassim University, KSA \\ *Corresponding author E-mail: safiah.mr@gmail.com
}

\begin{abstract}
Background: Health care providers as a trusted source of information for most patients should be able to provide counseling services to patients on the new concept of stem cells utilization, benefits and its practice implications.

Objective: this study aims to assess the knowledge and attitude of health care providers in Qassim region regarding stem cells.

Methods: Self-administered tools were utilized among 250 health care providers were chosen from five major hospitals in Qassim, including doctors, nurses, and other health care providers such as pharmacists, dietaries and administrative staff.

Results: The participants were female, $<30$ years in age, had practiced for $<10$ years and nurses. About $56 \%$ of respondents had a moderate knowledge regarding stem cells, and only $31.2 \%$ had good knowledge. About three quarters 191 (76.4\%) of the participants exhibited positive attitude towards stem cells use. A Pearson's correlation between knowledge and attitude scores was statistically significant. Conclusion: Data from the present study revealed the moderate levels of knowledge and positive attitude toward stem cells and its application among health care providers in Qassim. Therefore, this study suggests that educational programs on stem cells should be implemented to improve stem cells knowledge and encourage a more positive attitude.
\end{abstract}

Keywords: Attitude; Health Care Providers; Knowledge; Stem Cells.

\section{Introduction}

Stem cells are undifferentiated cells found in the human body that have the unique ability to divide continuously and having the ability to build every tissue in the human body, hence have the great potential for future therapeutic uses in tissue regeneration and repair (Acharya, 2013; Biehl\& Russell, 2014). Debate and discussions about stem cells are everywhere, including magazines, television, radio and the Internet. Complicating the topic even more is the political and government policies around stem cells research (Murnaghan, 2016). Scientists are excited about the knowledge that could come from studying human stem cells, and most of them believe that these cells offer a precious opportunity to learn more about cytopathology, including how diseases develop and how they might be prevented or treated on the cellular level (Lye et al., 2015).Stem cells are found in all multi cellular organisms, and are characterized by the ability to renew through mitotic cell division and differentiate into a diverse range of specialized cell types. The two broad types of mammalian stem cells are: embryonic stem cells that are isolated from the inner cell mass of blastocysts, and adult stem cells that are found in adult tissues (American College of Obstetricians and Gynecologists, 2011; Ma et al., 2012). Stem cell's transplant is a surviving procedure that can increase life expectancy of end-stage or chronically ill patients (Abdulqader et al., 2017).The The first transplant of stem cells was conducted in the year 1968 in the United States and since then, there has been tremendous development in this technology related to scientific research and technological advances in the medical field (Murnaghan, 2017). Even though many applications of stem cells are under investigation, such as research has raised high hopes and promises along with warnings and ethical and religious questions in different societies (Zahedi-Anaraki \& Larijani, 2011). Although, stem cells research related to hematopoietic stem cells are increasing worldwide with promises to human health, debate about stem cell's therapy is intense due to the involvement of scientific, religious, societal and political opinions. Discussions are often intense because of the different positions held by scientific, religious, social and political sources. These aspects are strongly associated with support for and opposition to stem-cell research in all regions (Allum et al., 2017). Most Muslim countries have not yet introduced laws on embryonic stem cell research. Some Muslims are in favor of research, arguing that the embryo does not have a soul until the later stages of its development (Ilkilic and Ertin, 2010). Kingdome of Saudi Arabia (KSA) emerged as the first country in the Arab world to record more than 10,000 stem cell donors, a unique medical feat that will encourage people to donate stem cells and promote stem cell therapy in the Kingdom to help people suffering with incurable diseases. Saudi bioethics committee was established in 2002 by Royal decree permits research using stem cells (Wadvalla, 2012). In 2003, the King Faisal Specialist Hospital and Research Center (KFSH-RC) began performing transplants using Cord blood (CB) Units imported from international registries. A public bank was created in 2006 at KFSH-RC, which now stores over 4600 units. As of 2013, it transplanted 121 locally stored units to 108 patients; 103 children and 5 adults (Al-Humaidan, 2012 \&Haydar, 2013). KFSH-RC has conducted 5020 cases since the hospital started this type of transplantation, including 323 in 2015, which includes 176 adult and 
147 children. Saudi Arabia emerged as the first country in 2015 from Arab world to record more than 10,000 stem cell donors, a unique medical feat that will encourage people to donate stem cells and promote stem cell therapy in the Kingdom to help people suffering with incurable diseases (Hassan, 2015).

This scientific innovation requires health care providers to prepare themselves with knowledge gained from specialized research and their own ethical decision (Yildirım \& Sahin, 2007). Awareness levels among the healthcare providers when increased, especially nurses about the concept and strong legalized and fewer commercialized environment can work positively towards making stem cell banking an integral part of healthcare. Hence, the researchers felt the need to assess the knowledge and attitude of healthcare providers on stem cell applications (Bethesda, 2015). In particular, nurses need to equip themselves with accurate information, using the international Council of Nursing Code of Ethics for nurses (Oulton, 2000) and their own ethical decision-making processes. They can then take decisions for themselves about the efficacy of stem cell research and then become important sources of knowledge and information to help others understand and debate the direction of this scientific breakthrough. Nurses can play a crucial role in providing first-hand information to the general public about stem cell, and they must be aware of the legal and ethical issues related to stem cell's procedures. Therefore, nurses need to hold a proper knowledge and attitude through appropriate education during their course of study. Nursing curriculum needs to remain up to date to be able to meet the standards of nursing practice (Miok \& Hyunmi, 2013; Abdullah, 2011, Mohammed \& Sayed, 2015; Moustafa \&Youness, 2015). In addition, Venugopal et al., (2016) reported that, stem cells were recent medical innovation, and physicians are challenged to integrate knowledge and attitude related to the newly developed concept in clinical practice.

\subsection{Significance of the study}

Because of the bright potential of stem cell-based treatment, it is vital for health care providers to keep abreast of current advances in stem cell science, particularly when there is an enormous potential of revolutionizing therapy in the form of cell replacement therapy (Lye et al., 2015). Health care providers are a trusted source of information for most patients, they need to be informed about the practices and indications for stem cells and be able to direct the patient as to where they can obtain additional information, so they can make an informed choice (Abdo, 2014). Therefore, that research into healthcare professionals' knowledge and attitudes concerning the stem cells conducted to identify gaps, which exist in knowledge that may influence health professional attitudes and practices towards informing expectant patients about their options (Peberdy et al, 2016). The aim of the current study is to assess the knowledge and attitude of health care providers in Qassim region regarding stem cells.

\section{Study methodology}

\subsection{Design and participants}

This study is a cross-sectional study focused on investigating the knowledge and attitude level of heath care providers in Qassim region towards stem cell application in medical setting. In this study, a total of two hundred and fifty respondents were recruited from five major hospitals in Qassim region. The sample included doctors, nurses, and other health care providers such as pharmacists, dietaries, lab technicians, and administrative staff. The researchers recruited the sample as the following: 17 doctors, 26 nurses, and 9 others from King Fahad Specialist Hospital (KFSH); 15 doctors, 25 nurses, and 11 others from Buraydah Central Hospital $(\mathrm{BCH}), 20$ doctors, 12 nurses, and 13 others from Maternity and Children Hospital (MCH), 11 doctors, 22 nurses, and 17 others from King Saud Hospital in Unaizah (KSH),19 doctors, 27 nurses, and 6 others from General Hospital in Al-Rass (GH) and in each hospital all departments were represented.

\subsection{Data collection tool}

The self-administered questionnaire which developed by the researchers based on the literature review regarding stem cells, and its application in the medical setting was utilized in the current study to assess knowledge and attitudes among health care providers in Qassim region. This tool contained three sections; the first section was made up of twelve questions concerning the sociodemographic characteristics of participants as gender, age, occupation, religion, marital status, Qualification, number of years in practice and nationality. The second section was made up of twenty-nine questions and the response consists of either yes, no, or I don't know. This section concerning the general knowledge of stem cells as their characteristics, types, potency, general sources, potential uses in a medical field in addition to the source of their information and knowledge regarding the application of stem cells (figure 1). The third section was made up of sixteen questions used to assess the response of the participants as regard to their attitude toward stem cells and its applications. The response to attitude question consists of either agree, disagree, or I don't know to the statements given

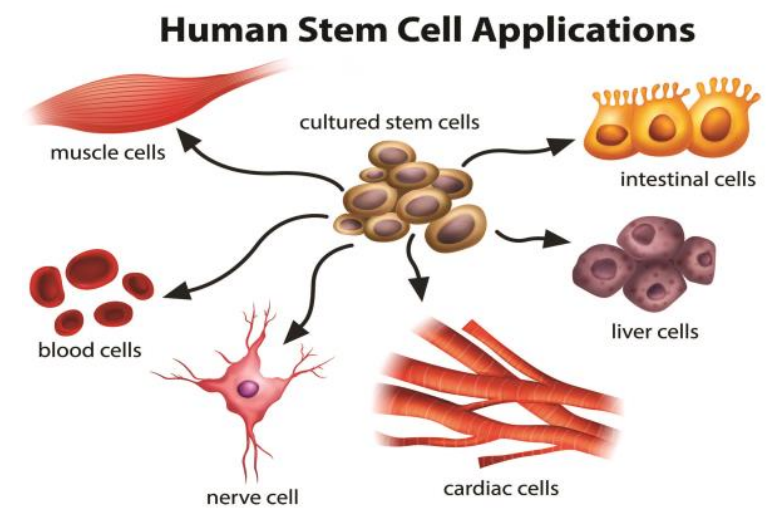

Fig. 1: Human Stem Cell Applications.

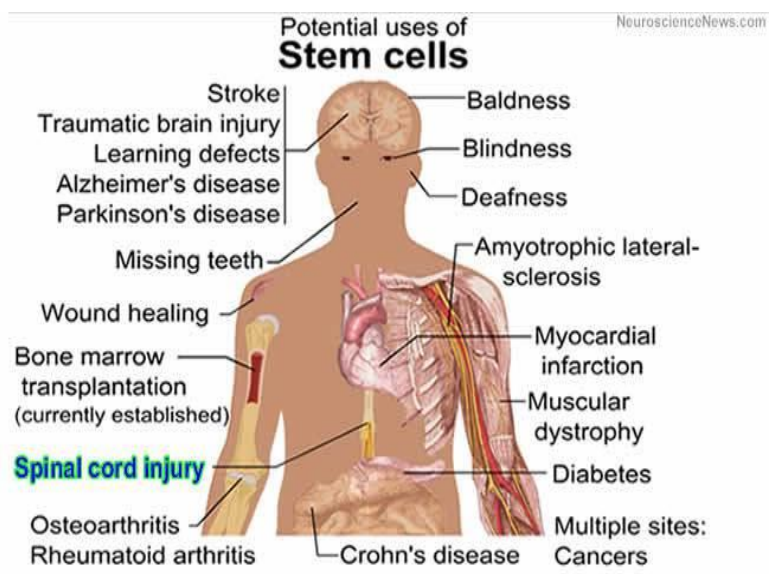

\subsection{Data collection procedure}

Once the ethical approval was granted from the academic and Hospitals' managers, a pilot study was conducted on $10 \%$ of nurses, physician and other health care providers from the King Saud Hospital to test feasibility of tool and time required to be applied. Simple modification was done of some items of the questionnaire that enhance the clarity of questions, and the participants of the pilot study were included in the study sample. Data collection resumed as the next stage of study using structured questionnaires with the health care providers. Each respondent was given one questionnaire and research information, which was to explain the 
purpose of the study, its voluntary nature, and the anonymity of the responses. The researchers explained the study and obtained the consent of the participant to complete the survey. Researchers had passed the questionnaire to the respondents and they were given approximately five minutes to complete the questionnaire Upon completion, the researchers collected the questionnaires.

\subsection{Data analysis and scoring measurements}

Data entry and statistical analysis were performed using the Statistical Package for Social Science (SPSS) program (version 22), for windows. Frequency and range verifications were carried out initially to detect errors in the data entry. Then detected errors were corrected by receiving the original data forms. Reliability was tested before the main data analysis and was reported as 0.905 for knowledge and 0.839 for attitude, which indicates a high level of reliability and internal consistency for our questionnaire. Descriptive analysis approach was used to determine the sociodemographic factors. Knowledge about stem cell's assessment included 29 questions with "Yes," "No" and "I don't know" as answers. A score of 2 was given to the right response, 1 to the false response and 0 to "I don't know" one. For each subject, a maximum score of 58 could be calculated. The knowledge level score was categorized into 3 levels indicated by Poor knowledge (0-19), Moderate knowledge (20-38) and Good knowledge (3958). Thus, the higher the score is the higher level of knowledge among health providers. To evaluate the attitude level, we had a resource to Likert 3-point scale questions, with "Agree," "Disagree" and "I don't know" responses. A score of 1 was given to not an approval response (which can be an "agree" or "disagree" response). A score of 2 was given to "I don't know" answer and a score of 3 were given to the approval response (which can be also an "agree" or "disagree" response). Since there were 16 questions, the range of score was from 16 to 48 . Thus, the Attitude score calculated was categorized into 3 levels: Do not approve (16-26), Unsure (27-37) and approve (38-48). To find out the correlation between knowledge and attitude Pearson's correlation was applied and for statistical significance, $\mathrm{p}$-value $<0.05$ were considered.

\subsection{Ethical considerations}

The approval to conduct this study was obtained from the research center at college of Nursing, Qassim University, and managers of the hospitals in which the study conducted. Prior to taking part in the study, all respondents were asked to agree or not to participate in the study. They were also explained about the purpose and objective of the study by the researchers. This research provided autonomy, allowing respondents the freedom to decide whether to participate and give information. All respondents of the study were assured that confidentiality would be maintained.

\section{Results}

\subsection{Demographics of the studied subjects}

Table (1) shows the socio-demographic characteristics of the study sample. A total of two hundred and fifty health care providers from $\mathrm{Al}$ Qassim region completed the survey; about $57.2 \%$ of them were female and $47.6 \%$ of participants were less than 30 years old. The majority was married $(62 \%)$, and $53.2 \%$ of them have children. Of the respondents; $52.4 \%$ had bachelor degree and $44.8 \%$ of subjects were nurses while almost the third of the sample (32.8\%) were physicians. Almost half of participants were Saudi (51.6\%), and most care providers were Muslims (79.6\%).

Table 1: Demographic Characteristics of the Participated Health Care Providers $(\mathrm{N}=250)$

\begin{tabular}{|c|c|c|c|}
\hline \multicolumn{2}{|c|}{ Characteristics } & \multirow[t]{2}{*}{ Frequency } & \multirow[t]{2}{*}{ Percent $(\%)$} \\
\hline Gender & & & \\
\hline & Male & 107 & 42.8 \\
\hline & Female & 143 & 57.2 \\
\hline \multicolumn{4}{|l|}{ Age } \\
\hline & $<30$ & 119 & 47.6 \\
\hline & $30-39$ & 82 & 32.8 \\
\hline & Equal or $>40$ & 49 & 19.6 \\
\hline \multicolumn{4}{|c|}{ Marital status } \\
\hline & Single & 91 & 36.4 \\
\hline & Married & 155 & 62.0 \\
\hline & Divorced & 4 & 1.6 \\
\hline \multicolumn{4}{|l|}{ Children } \\
\hline & Yes & 133 & 53.2 \\
\hline & No & 117 & 46.8 \\
\hline \multicolumn{4}{|c|}{ Qualification } \\
\hline & Diploma & 74 & 29.6 \\
\hline & Bachelor & 131 & 52.4 \\
\hline & Master \& higher & 45 & 18 \\
\hline \multicolumn{4}{|c|}{ Occupation } \\
\hline & Nurses & 112 & 44.8 \\
\hline & Physicians & 82 & 32.8 \\
\hline & Others (pharmacist, dietarian, lab technician, $\&$ administrative staff) & 56 & 22.4 \\
\hline \multicolumn{4}{|c|}{ Years of experience } \\
\hline & $<10$ years & 169 & 67.6 \\
\hline & $10-20$ years & 51 & 20.4 \\
\hline & $\geq 20$ & 30 & 12.0 \\
\hline \multicolumn{4}{|c|}{ Nationality } \\
\hline & Saudi & 129 & 51.6 \\
\hline & Non Saudi & 121 & 48.4 \\
\hline \multicolumn{4}{|l|}{ Religion } \\
\hline & Muslim & 199 & 79.6 \\
\hline & Non Muslim & 51 & 20.4 \\
\hline
\end{tabular}

\subsection{Level of knowledge about stem cells}

The knowledge regarding stem cells was evaluated according to the percentage of correct responses in 20 related statements. About
$75.6 \%$ of the respondents declared that stem cell is a sample cell in the body that is able to develop into any one of the various kinds of cell. Concerning the application of stem cells in treatment of diseases, $36.4 \%$ confirmed that stem cells can treat neurological diseases such as Alzheimer and Parkinson (Table 2). Regard- 
ing the source of information, Figure (2) shows that the primaries leading sources of information regarding stem cells were Seminar/conference $(39.2 \%)$ followed by Mass media (20.4\%) while Brochures $(2.4 \%)$ was the least source of information. In addition to $12 \%$ of participants had no information regarding stem cells and its applications. Table (3) shows that the respondents (56\%) have the moderate level of knowledge about stem cells and its applications, while only $31.2 \%$ have a good knowledge and the rest (12.8\%) had poor knowledge.

Table 2: Category of Knowledge among Health Care Providers Regarding Stem Cells

\begin{tabular}{|c|c|}
\hline Knowledge statement & $\begin{array}{l}\text { Frequency (\%) of correct } \\
\text { answer }\end{array}$ \\
\hline 1. Stem cell is sample cell in the body that is able to develop into any one of various kinds of cell & $189(75.6)$ \\
\hline 2. One of sources of stem cells is umbilical cord blood & $182(72.8)$ \\
\hline 3. Bone marrow stem cells are taken from the spine & $129(51.6)$ \\
\hline 4. Sperm and eggs are a source for adult stem cells. & $84(33.6)$ \\
\hline 5. Umbilical cord blood unit may be used for transplantation even after 25 years & $95(38.0)$ \\
\hline 6. Stem cells are cells that have the ability to produce other types of cells & $194(77.6)$ \\
\hline 7. We can use stem cells in treatment of diseases & $209(83.6)$ \\
\hline 8. Stem cells are unspecialized. & $94(37.6)$ \\
\hline 9. Stem cells can treat neurological diseases such as Alzheimer and Parkinson & $91(36.4)$ \\
\hline 10. Stem cells can treat the diabetes mellitus & $114(45.6)$ \\
\hline 11. Stem cells can treat spinal cord injuries and paralysis & $104(41.6)$ \\
\hline 12. Stem cells can treat heart diseases & $76(30.4)$ \\
\hline 13. Stem cells can treat infertility & $100(40.0)$ \\
\hline 14. Stem cells can treat tumor & $140(56.0)$ \\
\hline 15. Stem cells are capable of dividing and self-renew for long periods & $171(68.4)$ \\
\hline 16. Umbilical cord blood stem cells are embryonic stem cells & $161(64.4)$ \\
\hline 17. Embryonic stem cells are capable of forming any cell type in the body including placenta & $143(57.2)$ \\
\hline 18. Umbilical cord blood stem cell transplantation is less efficient compared with bone marrow stem cell transplantation & $78(31.2)$ \\
\hline 19. Embryonic stem cell transplantation has serious disadvantages as it could result in the formation of tumor. & $59(23.6)$ \\
\hline 20. In order a parent to donate umbilical cord blood, the delivery has to take place in big public hospital & $108(43.2)$ \\
\hline
\end{tabular}

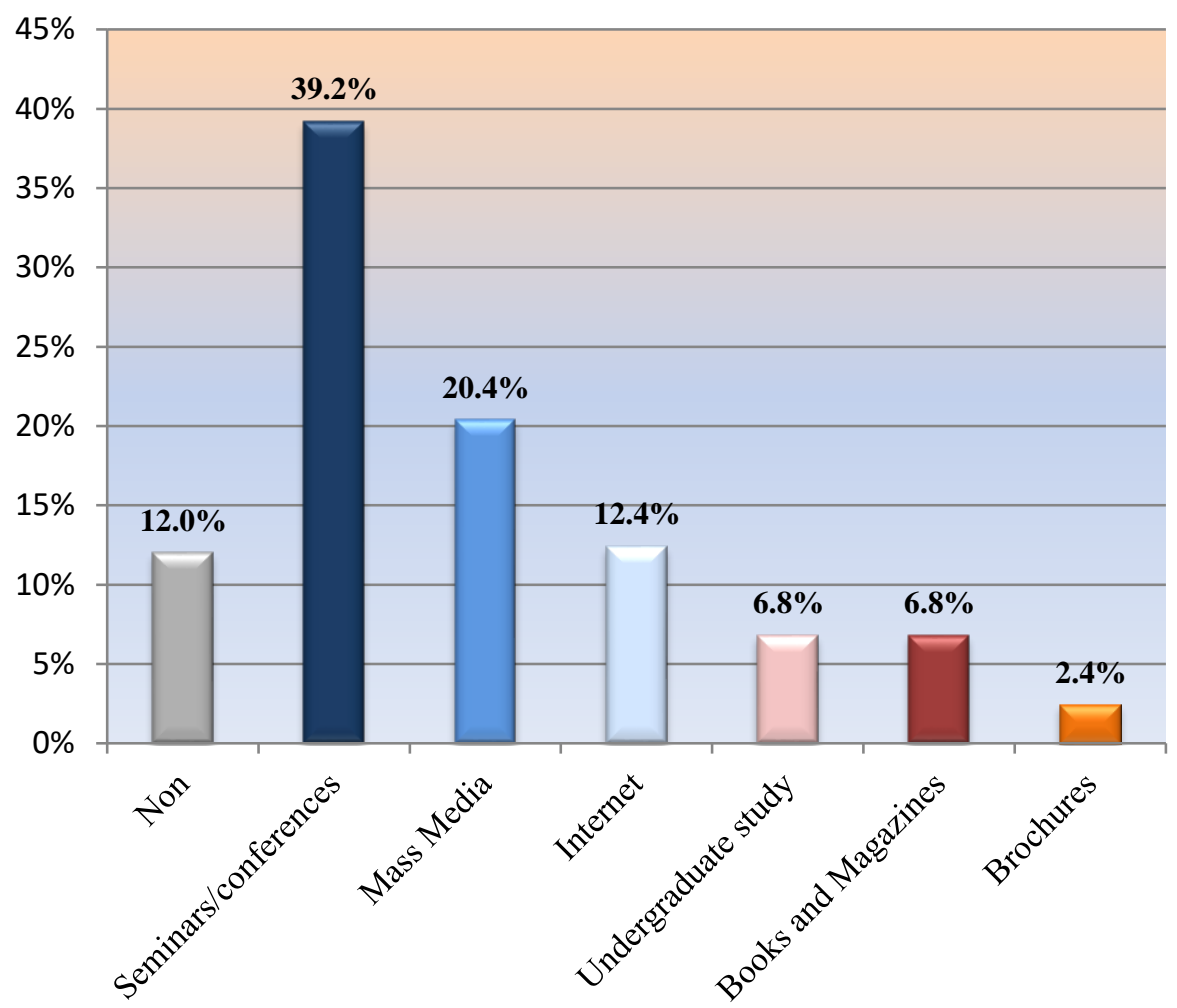

Fig. 2: Sources of Information Regarding Stem Cells among Health Care Providers

Table 3: Category of Knowledge about Stem Cells among Health Care Providers

\begin{tabular}{lll}
\hline Level of knowledge & Frequency & Percent $(\%)$ \\
\hline Good knowledge & 78 & 31.2 \\
Moderate knowledge & 140 & 56.0 \\
Poor knowledge & 32 & 12.8 \\
Total & 250 & 100.0 \\
\hline
\end{tabular}

\subsection{Attitude toward stem cells application}

Attitude questions are regrouped in table 4: ethically (Q1, Q2, Q12, Q13), third of participants (33.6\%) were worried that it might induce human killing, where slightly more than the quarter (26.4\%) were against researches on embryo or aborted fetus, while $87.2 \%$ believed to maintain the privacy of donor records and $83.6 \%$ insisted that a clear informed consent should be claimed before and after umbilical blood manipulation. On the religious level (Q3, Q11), 38\% of concerned health professionals found 
immoral to take a human life even if it belongs to an embryo and only $25.2 \%$ thought that stem cell collecting is approved by religious men. Culturally (Q4, Q5),), the majority of the studied subjects $(72.4 \%)$ reported that stem cell transplantation should be widely practiced and more than the half of respondents $(55.6 \%)$ mentioned that they would advise a pregnant mother to store her baby umbilical cord blood stem cells for future purposes. On a professional level (Q6, Q10), the major proportion of respondents $(85.6 \%)$ found primordial to acquire competences stem cell application knowledge and $88.4 \%$ confirmed their willingness to attend workshops about umbilical cord blood collection and stem cells.
Almost all the studied subjects (91.6\%) agreed that more awareness programs regarding stem cell should be conducted, and also a great majority $(83.2 \%)$ reported that mankind future would be brighter in case of successful application of stem cell. While a proportion of $29.2 \%$ found that patients are willing to accept poor QOL after stem cell, 65.2\% agreed on the fact that stem cell transplantation could be a life-saving treatment. With regards to the attitude category; table (5) showed that about three quarters 191 (76.4\%) of the participants exhibited positive attitude towards stem cells use.

Table 4: Percentage of Agreement of Health Care Providers with Attitude Statements Regarding Stem Cells

\begin{tabular}{|c|c|}
\hline Attitude statements & $\begin{array}{l}\text { Frequency }(\%) \text { of « Agree » re- } \\
\text { sponse }\end{array}$ \\
\hline $\begin{array}{l}\text { 1. I am worried that stem cells transplantation might potentially open doors to human being killed for the benefit } \\
\text { of others. }\end{array}$ & $84(33.6)$ \\
\hline 2. The government should prohibit all researches regarding embryonic stem cells from embryo or aborted fetus. & $66(26.4)$ \\
\hline $\begin{array}{l}\text { 3. Life begins at conception; thus. Embryonic stem cells research which involves the destruction of embryo is } \\
\text { immoral. illegal and unnecessary. }\end{array}$ & $95(38.0)$ \\
\hline 4. Stem cells transplantation should be widely practiced & $181(72.4)$ \\
\hline 5. I would advise pregnant mothers to store their umbilical cord blood stem cells for future purposes & $139(55.6)$ \\
\hline 6. Competency in stem cells knowledge is important for me as a health care provider & $214(85.6)$ \\
\hline 7. There should be more awareness program regarding stem cells & $229(91.6)$ \\
\hline 8. The future of mankind is bright if stem cells research could be successfully conducted & $208(83.2)$ \\
\hline 9. If I got a disease unable to cure by usual medical methods, I do recur by the treatment with stem cells & $158(63.2)$ \\
\hline 10. Accept to attend workshops about umbilical cord blood collection and stem cells & $221(88.4)$ \\
\hline Collecting stem cells is approved by religious men & $63(25.2)$ \\
\hline Must maintain the privacy of donor records & $218(87.2)$ \\
\hline $\begin{array}{l}\text { 13. Informed consent for collection, storage and use of cord blood should be obtained before delivery \& after } \\
\text { the adequate disclosure of information }\end{array}$ & 209 (83.6) \\
\hline 14. Cord blood collection centers should have clear policies about who must provide consent for donation & $220(88.0)$ \\
\hline The patient are willing to accept poor QOL after stem cells treatment & $73(29.2)$ \\
\hline Stem cells transplantation is a life saving treatment & $163(65.2)$ \\
\hline
\end{tabular}

Table 5:Category of Attitude Score toward Stem Cells Application among Participants

\begin{tabular}{lll}
\hline Attitude level & Frequency & Percent $(\%)$ \\
\hline Negative & 59 & 23.6 \\
Positive & 191 & 76.4 \\
Total & 250 & 100.0 \\
\hline
\end{tabular}

\subsection{Correlation between knowledge with attitude}

Nearly about one third (31.9\%) of participated health care providers have good knowledge and positive attitude and figure (3) indicated direct relationship between knowledge with attitude. The Chi-square test was applied and revealed a significant relation between the level of knowledge and the attitude level regarding stem cells since $\mathrm{p}$-value $=0.015<0.05$. However it is a weak relation (Cramer's V=0.183<0.5) as shown in table (6).

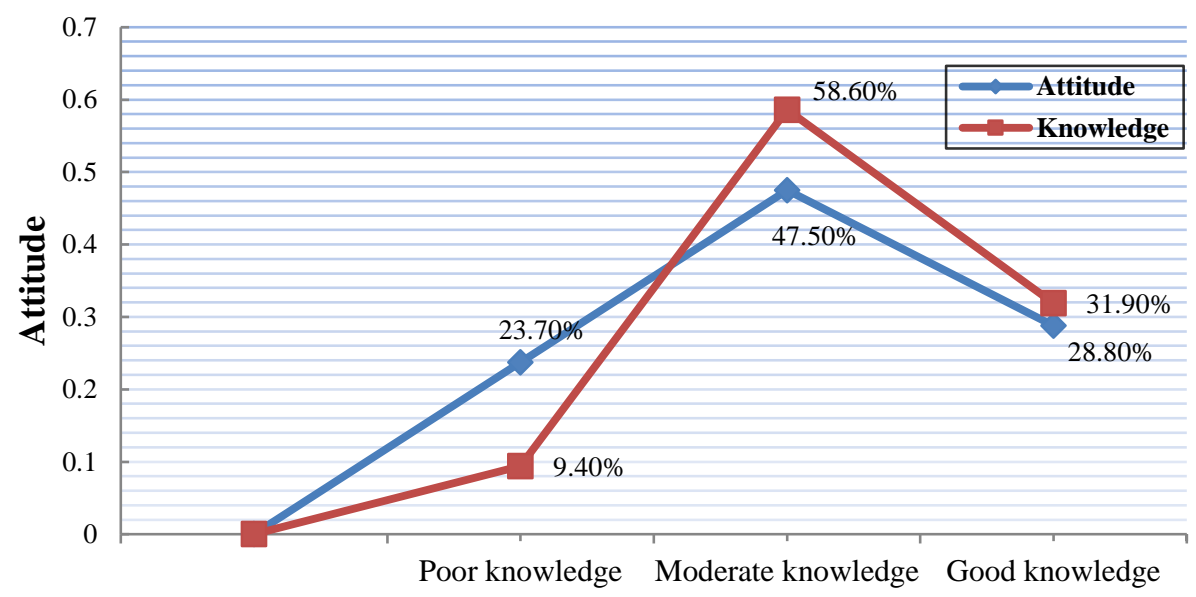

Fig. 3: Percentage of Knowledge and Attitude Scores toward Stem Cells. 
Table 6: Correlation between Knowledge and Attitude Scores toward Stem Cells

\begin{tabular}{|c|c|c|}
\hline & Value & P-value \\
\hline Pearson Chi-Square* & 8.353 & 0.015 \\
\hline Likelihood Ratio & 7.449 & 0.024 \\
\hline Linear-by-Linear Association & 3.358 & 0.067 \\
\hline Nominal by Nominal & 0.183 & 0.015 \\
\hline $\begin{array}{l}\text { Phi } \\
\text { Cramer's }\end{array}$ & 0.183 & 0.015 \\
\hline
\end{tabular}

*Pearson Chi-Square $(\mathrm{p}<0.05)$ indicated significant correlation

\section{Discussion}

Stem cells are master cells that can form virtually any tissue in the human body. Hence, stem cells research is one of the most important and, at the same time, the most controversial topics of science and technology today (Philip and Devi, 2017). The present study sought to assess health care providers' knowledge and attitude regarding stem cells, as their good knowledge and positive attitude will provide a trusted source of information, which enhances patients in decision making regarding use of stem cells as a recent innovation in treatment. The results of our research indicate that the most primary sources of information that health care providers are properly informed about stem cells are the seminars/conferences $(39.2 \%)$ followed by mass media $(20.4 \%)$, while $12 \%$ reported that they had no information regarding stem cells. In accordance of these findings, Moustafa \&Younes (2015) reported similar sources of information from their study of maternity nurses with the main sources being books and magazines $(39.3 \%)$ followed by seminars and conferences $(14 \%)$. In spite of recommendations of many recent researches (Miok \& Hyunmi, 2013; Abdullah, 2011, Mohammed \& Sayed, 2015; Moustafa \&Youness, 2015) that medical and nursing curriculum needs to remain up to date to be able to meet the standards of practice, our results reported that only $6.8 \%$ of participants learned about stem cells from undergraduate study. The majority of participants $(85.6 \%)$ expressed interest in developing their knowledge about stem cells; this finding is in agreement with Duffy et al., (2009) for participant maternity nurses who expressed a desire for further information on cord blood banking through training courses and educational programs. Similarly, Walker et al., (2012) reported that obstetricians indicated a desire for more information on cord blood banking. Mohammed and El Sayed (2015) revealed that $98.8 \%(\mathrm{n}=52)$ of nurses had not attended stem cells training courses, which is in compliance with our findings; where $76.0 \%$ of our participants had never attended training courses on stem cells. An overall moderate knowledge about the stem cells in the study was noted among more than half $140(56 \%)$ of the participants. In contrast, two other studies concerning maternity nurses reported that most maternity nurses had a low knowledge levels of stem cells and its uses (Moustafa \& Youness, 2015; Mohammed and El Sayed, 2015). In addition to the finding of recent study (Khalil and Sharshor, 2016) that assessed the Nurses' Knowledge about stem cells in paediatric Intensive Care Unit and paediatric Hematology Department in Tanta, Egypt and also reported that Nurses' Knowledge about stem cells is inadequate in $69 \%$ of participants Inconsistency with our finding also found with the study conducted in Greece by Hatzistilli et al., (2014) to exam in health professionals' knowledge and attitudes towards Umbilical Cord Blood and declared only $15.6 \%(n=109)$ of the Health professionals are well informed on the collection and usage of Umbilical Cord Blood. This discrepancy may be due to the difference in study setting; the current study conducted in Qassim, Kingdome of Saudi Arabia (KSA), where the majority of health care providers are foreigners (non-Saudi) and KSA recruited the knowledgeable and professional staff. The optimistic element in our findings that more than three quarters $191(76.4 \%)$ of the participants exhibited a positive attitude towards stem cells use. Similarly, a study of Sede et al., (2013) among dentists from private and public health sectors in Nigeria revealed nearly similar percentage $142(75.1 \%)$ exhibited a positive attitude towards stem cells use in dentistry.
This high level of positive attitude can be explained by the relatively high level of knowledge about stem cells noted in this study. The present study applied Pearson Chi-Square to test the correlation between knowledge and attitude. The result (8.353, pvalue 0.015) indicated a significant correlation between knowledge and attitude of health care providers. Similarly, a positive correlation between knowledge and attitude scores of nurses $(\mathrm{r}=0.532, \mathrm{p}<0.01)$ was confirmed by Venugopal et al., (2016) among nurses working in labor room $(\mathrm{n}=56)$. This finding is incongruence with the recent study (Lye et al., 2015) who found that the association between the undergraduate nursing students knowledge and attitude score of stem cells was poor, which was indicated by the correlation coefficient $(r=0.08)$. This study did have limitations that should be addressed. First, the lower response rate could have resulted in a selection bias favoring health care providers among respondents who are more knowledgeable and motivated on topics of stem cells. Respondents are likely to be motivated to answer a survey if they are interested and knowledgeable in a topic (Klabunde et al., 2013). Another limitation of this study is that we surveyed health care providers affiliated to Qassim region. Therefore, our results may not be generalizable to other geographic areas in KSA.

\section{Acknowledgements}

The authors gratefully acknowledge all health care providers who so willingly participated in this study. As well the Research Center-college of nursing that approved the proposal and tool for data collection.

\section{Funding}

The author received no direct funding for this research.

\section{Conflict of interest}

None declared

\section{References}

[1] Abdo A.R. (2014): Health care Provider Knowledge and Attitude Regard Uses of Stem Cells and Cord Banks. Published Master thesis, Accessed on $27^{\text {th }}$ Jan.2016. Available At [http://library.shams.edu.eg/eulc_v5/Libraries/Thesis/BrowseThesis Pages.aspx?fn].

[2] Abdullah, Y. (2011). Cord Blood Banking: What nurses and health care providers should know? American Journal of Maternal Child Nursing, 36(6), 334 350.https://doi.org/10.1097/NMC.0b013e31822db253.

[3] Abdulqader A., AlMulhim A., AlMulhim F., \&Almubarak H. (2017): Knowledge and Attitude of Blood, Organ and Stem Cells Donation among Al Ahssa Population. International Journal of Academic Scientific Research. 5(1):40-53.

[4] Acharya S. (2013). Perception of Dental Scientists and PostGraduate Students Regarding Future Prospects of Stem Cells in Dentistry. Acta stomatology Croat, 47(4), 312 21.https://doi.org/10.15644/asc47/4/3.

[5] Allum, N. Allansdottir, A. Gaskell, G. Hampel, J. Jackson, J. Moldovan A., Susanna Priest,S. Stares,S. and StonemanP. (2017): Religion and the public ethics of stem-cell research: Attitudes in Europe, Canada and the United States. PLoS ONE 12(4): e0176274. https://doi.org/10.1371/journal.pone.0176274. 
[6] American College of Obstetricians and Gynecologists. FAQ 172 Cord blood banking. 2011. Available from: http://www.acog.org/ /media/For\%20Patients/faq172.pdf?dmc.

[7] Al-Humaidan H. Umbilical cord blood transplantation: Saudi Arabia experience (presentation). Qatar International Conference on Stem Cell Science and Policy. Doha, Qatar. February 28, 2012.https://doi.org/10.5339/qproc.2012.stem.1.22.

[8] Bethesda, M.D. Bone Marrow Transplantation and Peripheral Blood Stem Cell Transplantation In National Cancer Institute Fact Sheet web site: National Institutes of Health, U.S. Department of Health and Human Services, 2010. Cited 24 August 2015

[9] Biehl, J. K., \& Russell, B. (2009). Introduction to Stem Cell Therapy. The Journal of Cardiovascular Nursing, 24(2): 98-105. Available at [https://www.ncbi.nlm.nih. gov/pmc/articles/PMC4104807/].https://doi.org/10.1097/JCN.0b01 3e318197a6a5.

[10] Duffy T, Querol S, Dennes W, Tarrio M, Mason K, Bushby H, Okeke W, Goldman J, Madrigal J, Muffti G, Pagliuca A, Yiannouzis K. The Kingscord model: a public cord blood collection service. $\mathrm{Br}$ J Midwifery. 2009; 17(4):30613.https://doi.org/10.12968/bjom.2009.17.5.42224.

[11] Hatzistilli H., Zissimopoulou O., Galanis P., Siskou O., Prezerakos P., Zissimopoulos A. and Kaitelidou D.(2014): Health Professionals' knowledge and attitude towards the Umbilical Cord Blood donation in Greece. Hippokratia, 18, 2: 110-115.

[12] Haydar M. Stem cells bank in King Faisal Specialist Hospital houses secrets of cells [translated from Arabic]. Al-Riyadh newspaper, April, 24, 2013. Available at: http://www.alriyadh.com/828855. Accessed on June 24, 2017.

[13] Ilkilic I. and ErtinH. (2010): Ethical Aspects of Human Embryonic Stem Cell Research in the Islamic World: Positions and Reflections. Stem Cell Reviews and Reports. 2010 Jun; 6(2):151-61. https://doi.org/10.1007/s12015-010-9117-6.

[14] Khalil, A. M. and Sharshor S. M. (2016): Pediatric Nurses Knowledge, Awareness and Attitude towards Application of Stem Cells Therapy in Children. IOSR Journal of Nursing and Health Science. Volume 5, Issue 4 Ver. III (Jul. - Aug.), PP 88-96.

[15] Klabunde, C.N., Willis, G.B., and Casalino, L.P. Facilitators and barriers to survey participation by physicians: a call to action for researchers. Eval Health Prof. 2013; 36: 279295.https://doi.org/10.1177/0163278713496426.

[16] Miok, K., Hyunmi, A. H. (2013). Student Nurses' Knowledge, Attitude, and Intention for Hematopoietic Stem Cell Donation in Korea. Advances in Information Sciences and Service Sciences, 5 (15), 145-151.

[17] Mohammed, H. S. and EL Sayed, H. A. (2015). Knowledge and Attitude of Maternity Nurses Regarding Cord Blood Collection and Stem Cells: An Educational Intervention. Journal of Nursing Education and Practice, 5(4), 5869.https://doi.org/10.5430/jnep.v5n4p58.

[18] Moustafa MF, Youness EM. Nurses' knowledge about umbilical cord blood banking and its barriers. IOSR J Nurs Health Sci. 2015; 4(2):44-53.

[19] Murnaghan I. (2016): What are Stem Cells? Accessed on $25^{\text {th }}$ Jul. 2017. Available at [http://www.explorestemcells.co.uk/WhatAreStemCells.html].

[20] Murnaghan I. (2017): History of Stem Cell Research. Accessed on $7^{\text {th }} \quad$ October $2017, \quad$ available at http://www.explorestemcells.co.uk/historystemcellresearch.html

[21] Hassan R. (2015): KSA First in Arab World to Have over 10,000 Stem Cell Donors. Accessed on $4^{\text {th }}$ FEB.2016. Available At [http://www.arabnews.com/featured/news/ 789086].

[22] Ma X., Zhang Q., Yang X., \&Tian J. (2012): Development of New Technologies for Stem Cell Research. Journal of Biomedicine and Biotechnology. $\quad$ Vol. 2012: 7 pages https://doi.org/10.1155/2012/741416.

[23] Moustafa M. F. \&Youness E.M (2015): Nurses, Knowledge about Umbilical Cord Blood Banking and its Barriers. IOSR Journal of Nursing and Health Science. Volume 4, Issue 2: PP 44-53.

[24] Lye, J. L., Soon, L.K., Nizam, W.A., Ahmad, W., Tan, S. C. (2015). Knowledge and Attitude about Stem Cells and Their Application in Medicine among Nursing Students in University Saints Malaysia, Malays Journal of Medical Science, 22(4), 23-31.

[25] Peberdy L., Young J., \& Kearney L. (2016): Health care professionals' knowledge, attitudes and practices relating to umbilical cord blood banking and donation: an integrative review. BMC Pregnancy and Childbirth. 16, 81. https://doi.org/10.1186/s12884016-0863-6.
[26] Philip N. and Devi. S. 2017, Improve The Knowledge And Attitude of Antenatal Mothers Regarding Umbilical Cord Stem Cell Banking. Int J Recent Sci Res. 8(6), pp. 17303-17308.

[27] Sede M. A., Audu O. and Azodo C.C. (2013): Stem cells in Dentistry: knowledge and attitude of Nigerian Dentists. BMC Oral Health 2013, 13:27. https://doi.org/10.1186/1472-6831-13-27.

[28] Wadvalla BA. Stem cell research and Islamic regulations. Nature. Available http://www.natureasia.com/en/nmiddleeast/article/10.1038/middlee ast.2012.125. Accessed 10th November, 2016.

[29] Walker T, Steckler D, Spellman S, Haven D, Welte K, Boo M. Awareness and acceptance of public cord blood banking among practicing obstetricians in the United States. Transfusion. 2012; 52(4):787-93.https://doi.org/10.1111/j.1537-2995.2011.03383.x.

[30] Zahedi-Anaraki F. \&Larijani B. (2011) Stem Cells: Ethical and Religious Issues. Accessed on $25^{\text {th }}$ Nov.2011. Available at [https://www.intechopen.com/books/statistics/ bioethics-in-the21st-century/stem-cells-ethical-and-religiousissues].https://doi.org/10.5772/19298.

[31] Venugopal A., Joshi P., Deka D., Seth T. (2016): Knowledge and attitude of nurses regarding stem cells and umbilical cord blood banking in a selected tertiary care facility. Asian J. Nursing Edu. \& Research 6(2): April- June 2016.https://doi.org/10.5958/23492996.2016.00046.X.

[32] Yildırım, G. \&Sahin, N.H. (2007). Stem cell transplantation and nursing approach. Nursing Journal, 60 (15), 25-31. Available at: http://www.istanbul.edu.tr/yuksekokullar/ floren/Hemsirelik\%20Dergisi/sayi60_makale_9.pdf (accessed on 11 $1^{\text {th }}$ June 2017).

[33] Oulton. J.A, the International Council of Nursing Code of Ethics for Nurses (ICN). International Nursing Review journal; 2000, 47(3), $138-141$. 